\title{
Barium chloride injures myofibers through calcium-induced proteolysis with fragmentation of motor nerves and microvessels
}

Aaron B. Morton ${ }^{1 \dagger}$, Charles E. Norton ${ }^{1 \dagger}$, Nicole L. Jacobsen ${ }^{1}$, Charmain A. Fernando ${ }^{1}$, D. D. W. Cornelison ${ }^{2}$ and Steven S. Segal ${ }^{1,3^{*}}$ (i)

\begin{abstract}
Background: Local injection of $\mathrm{BaCl}_{2}$ is an established model of acute injury to study the regeneration of skeletal muscle. However, the mechanism by which $\mathrm{BaCl}_{2}$ causes muscle injury is unresolved. Because $\mathrm{Ba}^{2+}$ inhibits $\mathrm{K}^{+}$ channels, we hypothesized that $\mathrm{BaCl}_{2}$ induces myofiber depolarization leading to $\mathrm{Ca}^{2+}$ overload, proteolysis, and membrane disruption. While $\mathrm{BaCl}_{2}$ spares resident satellite cells, its effect on other tissue components integral to contractile function has not been defined. We therefore asked whether motor nerves and microvessels, which control and supply myofibers, are injured by $\mathrm{BaCl}_{2}$ treatment.
\end{abstract}

Methods: The intact extensor digitorum longus (EDL) muscle was isolated from male mice (aged 3-4 months) and irrigated with physiological salt solution (PSS) at $37^{\circ} \mathrm{C}$. Myofiber membrane potential $\left(V_{m}\right)$ was recorded using sharp microelectrodes while intracellular calcium concentration $\left(\left[\mathrm{Ca}^{2+}\right]_{i}\right)$ was evaluated with Fura 2 dye. Isometric force production of EDL was measured in situ, proteolytic activity was quantified by calpain degradation of all-spectrin, and membrane disruption was marked by nuclear staining with propidium iodide (PI). To test for effects on motor nerves and microvessels, tibialis anterior or gluteus maximus muscles were injected with $1.2 \% \mathrm{BaCl}_{2}(50-75 \mu \mathrm{L})$ in vivo followed by immunostaining to evaluate the integrity of respective tissue elements post injury. Data were analyzed using Students $t$ test and analysis of variance with $P \leq 0.05$ considered statistically significant.

Results: Addition of $1.2 \% \mathrm{BaCl}_{2}$ to PSS depolarized myofibers from $-79 \pm 3 \mathrm{mV}$ to $-17 \pm 7 \mathrm{mV}$ with a corresponding rise in $\left[\mathrm{Ca}^{2+}\right]_{\text {i; }}$ isometric force transiently increased from $7.4 \pm 0.1 \mathrm{~g}$ to $11.1 \pm 0.4 \mathrm{~g}$. Following $1 \mathrm{~h}$ of $\mathrm{BaCl}_{2}$ exposure, $92 \pm 3 \%$ of myonuclei stained with PI (vs. $8 \pm 3 \%$ in controls) with enhanced cleavage of all-spectrin. Eliminating $\mathrm{Ca}^{2+}$ from PSS prevented the rise in $\left[\mathrm{Ca}^{2+}\right]_{\mathrm{i}}$ and ameliorated myonuclear staining with $\mathrm{PI}$ during $\mathrm{BaCl}_{2}$ exposure. Motor axons and capillary networks appeared fragmented within $24 \mathrm{~h}$ following injection of $1.2 \% \mathrm{BaCl}_{2}$ and morphological integrity deteriorated through $72 \mathrm{~h}$.

Conclusions: $\mathrm{BaCl}_{2}$ injures myofibers through depolarization of the sarcolemma, causing $\mathrm{Ca}^{2+}$ overload with transient contraction, leading to proteolysis and membrane rupture. Motor innervation and capillarity appear disrupted concomitant with myofiber damage, further compromising muscle integrity.

Keywords: Skeletal muscle, Motor innervation, Capillary supply, Neuromuscular junction

\footnotetext{
* Correspondence: segalss@health.missouri.edu

${ }^{+}$Aaron B. Morton and Charles E. Norton are co-first authors.

${ }^{1}$ Department of Medical Pharmacology and Physiology, University of

Missouri, MA415 Medical Sciences Building, 1 Hospital Drive, Columbia, MO

65212, USA

${ }^{3}$ Dalton Cardiovascular Research Center, Columbia, MO 65211, USA

Full list of author information is available at the end of the article
}

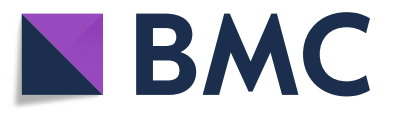

(c) The Author(s). 2019 Open Access This article is distributed under the terms of the Creative Commons Attribution 4.0 International License (http://creativecommons.org/licenses/by/4.0/), which permits unrestricted use, distribution, and reproduction in any medium, provided you give appropriate credit to the original author(s) and the source, provide a link to the Creative Commons license, and indicate if changes were made. The Creative Commons Public Domain Dedication waiver (http://creativecommons.org/publicdomain/zero/1.0/) applies to the data made available in this article, unless otherwise stated. 


\section{Background}

Acute injury to skeletal muscle initiates a coordinated process of tissue degeneration and regeneration that encompasses inflammation; digestion of damaged components; activation, proliferation, and differentiation of resident myogenic stem cells (satellite cells); and maturation of nascent myofibers [1,2]. While different injury models (freeze injury, cardiotoxin, Marcaine ${ }^{\mathrm{Tw}}$, and $\mathrm{BaCl}_{2}$ ) induce variable degrees of tissue damage and inflammation [3-5], the advantages of chemical injury with $\mathrm{BaCl}_{2}$ include both ease of use and its ability to reproducibly damage myofibers while preserving their associated satellite cells [3, 6-9] (Additional file 1). However, the mechanism by which $\mathrm{BaCl}_{2}$ exposure leads to the death of skeletal muscle myofibers has not been identified. The divalent cation $\mathrm{Ba}^{2+}$ blocks inward rectifying potassium channels $\left(\mathrm{K}_{\mathrm{IR}}\right)$ at concentrations of 10 $100 \mu \mathrm{M}[10]$ and serves as a broad spectrum $\mathrm{K}^{+}$channel inhibitor at concentrations $\geq 1 \mathrm{mM}[11,12]$. Thus, injection of $1.2 \% \mathrm{BaCl}_{2}(\sim 57 \mathrm{mM})$, as used to induce muscle damage [3, 6-9], would be predicted to depolarize myofibers. In turn, depolarization can activate L-type voltage-gated calcium channels $\left(\mathrm{Ca}_{\mathrm{V}} 1.1\right)$ in the sarcolemma, leading to increases in intracellular $\mathrm{Ca}^{2+}$ concentration $\left(\left[\mathrm{Ca}^{2+}\right]_{\mathrm{i}}\right)$ via release from the sarcoplasmic reticulum and influx from the extracellular fluid $[13,14]$. Sufficient elevation of $\left[\mathrm{Ca}^{2+}\right]_{i}$ initiates proteolysis, leading to degradation of contractile proteins and cell membranes $[15,16]$. We therefore tested the hypothesis that $\mathrm{BaCl}_{2}$ injures skeletal muscle through myofiber depolarization, with elevated $\left[\mathrm{Ca}^{2+}\right]_{\mathrm{i}}$ leading to proteolysis and rupture of the sarcolemma.

Motor axons and microvessels are intimately associated with myofibers. At the neuromuscular junction (NMJ), myelinated axons projecting from $\alpha$ motor neurons in the spinal cord terminate and are covered by perisynaptic Schwann cells which overlay postsynaptic clusters of nicotinic acetylcholine receptors [17]. Arterioles control the perfusion of capillary networks that collectively span the entire length of myofibers to provide oxygen and nutrients essential to supporting contractile activity [18]. While $\mathrm{BaCl}_{2}$ can damage the capillary supply [3], it is unknown whether concomitant injury occurs to the motor nerves that control myofiber contraction. Therefore, also we tested whether local injection of $\mathrm{BaCl}_{2}$ disrupts the integrity of NMJs and capillaries concomitant with injuring myofibers.

\section{Methods}

\section{Aim, design, and setting}

The aim of this study was to determine how $\mathrm{BaCl}_{2}$ injures skeletal muscle myofibers and whether motor innervation and microvascular supply are concomitantly disrupted by exposure to $\mathrm{BaCl}_{2}$. We studied the acute effects of $\mathrm{BaCl}_{2}$ exposure on membrane potential $\left(\mathrm{V}_{\mathrm{m}}\right)$, $\left[\mathrm{Ca}^{2+}\right]_{\mathrm{i}}$, membrane integrity, $\alpha \mathrm{II}-$ spectrin degradation, and force production in extensor digitorum longus (EDL) muscles. Neuromuscular synapses were studied in the tibialis anterior (TA) muscle and the microcirculation was studied in the gluteus maximus (GM) muscle at 0 (control) and 1-3 days post injury (dpi) following local injection of $\mathrm{BaCl}_{2}$.

\section{Animal care and use}

All protocols and experimental procedures were reviewed and approved by the Animal Care and Use Committee of the University of Missouri (Columbia, MO, USA). Procedures were performed on male mice (age, 3-4 months; weight, $\sim 30 \mathrm{~g}$ ) of the following strains: C57BL/6J (WT) (Jackson Labs, $n=31$ ), D2$\mathrm{Tg}$ (S100B-EGFP)1Wjt/J (S100B-GFP) (Jackson Labs, $n=$ 6); and Cdh5-CreER ${ }^{\mathrm{T} 2}: R O S A-\mathrm{mTmG}$ (Cdh5-mTmG) (cross of VE-cadherin-CreER ${ }^{\mathrm{T} 2}$ mice [19] and

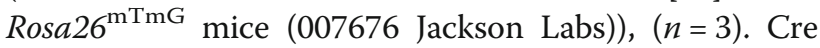
recombination was induced through intraperitoneal injection of $100 \mu \mathrm{g}$ tamoxifen (Cat. \# T5648, SigmaAldrich; St. Louis, MO, USA; $1 \mathrm{mg} / 100 \mu \mathrm{L}$ in peanut oil) on 3 consecutive days with at least 1 week allowed prior to further study. Mice were housed locally on a 12-h light-dark cycle at $\sim 23^{\circ} \mathrm{C}$, with freshwater and food available ad libitum.

To induce muscle injury in vivo, mice were anesthetized with ketamine and xylazine $(100 \mathrm{mg} / \mathrm{kg}$ and $10 \mathrm{mg} /$ $\mathrm{kg}$, respectively; intraperitoneal injection), the skin was shaved over the muscle of interest, and then $1.2 \% \mathrm{BaCl}_{2}$ was injected unilaterally into the TA $(50 \mu \mathrm{L}$ [9]) or under the GM $(75 \mu \mathrm{L}[8])$ as described. Mice were kept warm during recovery and then returned to their cage. On the day of an experiment, mice were anesthetized (as above). Following tissue harvest, mice were killed by exsanguination.

\section{Membrane potential}

The EDL muscle was used for these experiments because it can be isolated and secured in vitro by its tendons to approximate in vivo muscle length without damaging myofibers. An EDL muscle was removed from the anesthetized mouse, pinned onto transparent rubber (Sylgard 124; Midland, MI, USA), placed in a tissue chamber (RC-37 N; Warner Instruments; Hamden, CT, USA), transferred to the stage of a Nikon 600FN microscope (Tokyo, Japan), and irrigated $\left(3 \mathrm{~mL} \mathrm{~min}^{-1}\right)$ with standard physiological salt solution (PSS; pH 7.4) of the following composition: $140 \mathrm{mM} \mathrm{NaCl}$ (Fisher Scientific; Pittsburgh, PA, USA), $5 \mathrm{mM} \mathrm{KCl} \mathrm{(Fisher),} 1 \mathrm{mM} \mathrm{MgCl}_{2}$ (Sigma), $10 \mathrm{mM}$ HEPES (Sigma), $10 \mathrm{mM}$ glucose (Fisher), and $2 \mathrm{mM} \mathrm{CaCl}_{2}$ (Fisher) while maintained at $37^{\circ} \mathrm{C}$. 
The membrane potential $\left(V_{m}\right)$ of myofibers was recorded with an amplifier (AxoClamp 2B, Molecular Devices; Sunnyvale, CA, USA) using sharp microelectrodes pulled (P-97, Sutter Instruments; Novato, CA, USA) from glass capillary tubes (GC100F-10, Warner, Hamden, CT, USA) filled with $2 \mathrm{M} \mathrm{KCl}(\sim 150 \mathrm{M} \Omega)$ with a $\mathrm{Ag} / \mathrm{AgCl}$ pellet serving as a reference electrode [20]. The amplifier was connected to a data acquisition system (Digidata 1322A, Molecular Devices) and an audible baseline monitor (ABM-3, World Precision Instruments; Sarasota, FL, USA). Successful impalements were indicated by sharp negative deflection of $\mathrm{V}_{\mathrm{m}}$, stable $\mathrm{V}_{\mathrm{m}}$ for $>1 \mathrm{~min}$, and prompt return to $\sim 0 \mathrm{mV}$ upon withdrawal of the electrode. Data were acquired at $1 \mathrm{kHz}$ on a personal computer using AxoScope 10.1 software (Molecular Devices). Once a single myofiber was impaled, $V_{m}$ was recorded for at least $5 \mathrm{~min}$ to establish a stable baseline. PSS containing $1.2 \% \mathrm{BaCl}_{2}$ then irrigated the muscle at $37^{\circ} \mathrm{C}$. Additional experiments were performed using isotonic substitution of $\mathrm{BaCl}_{2}$ for $\mathrm{NaCl}$ (final $[\mathrm{NaCl}]=54 \mathrm{mM}$ vs. $140 \mathrm{mM}$ in standard PSS) to test whether differences in osmolality affected responses during exposure to $1.2 \% \mathrm{BaCl}_{2}$. Each of these experiments represents one myofiber in one EDL; each muscle was obtained from a separate mouse.

\section{Calcium photometry}

Intracellular $\left[\mathrm{Ca}^{2+}\right]$ responses were measured as reported [20]. An EDL muscle was incubated in either standard PSS or in $\mathrm{Ca}^{2+}$-free PSS containing $3 \mathrm{mM}$ (ethylene glycol-bis ( $\beta$-aminoethyl ether)-N,N, $\mathrm{N}^{\prime}, \mathrm{N}^{\prime}$-tetraacetic acid (EGTA)). Each solution contained $1 \mu \mathrm{M}$ Fura 2-AM (Cat. \# F4185, Fisher); a muscle was incubated for 60 min at $37^{\circ} \mathrm{C}$ and then washed for $20 \mathrm{~min}$ to remove excess dye. The $1.2 \% \mathrm{BaCl}_{2}$ was then added while fluorescence was recorded at $510 \mathrm{~nm}$ during alternative excitation $(10 \mathrm{~Hz})$ at $340 \mathrm{~nm}$ and $380 \mathrm{~nm}$ using a $\times 20$ objective (Nikon Fluor20, numerical aperture $(\mathrm{NA})=$ $0.45)$. Data were acquired using IonWizard 6.3 software (IonOptix; Milford, MA) on a personal computer and expressed as fluorescence $(\mathrm{F})$ ratios $\left(\mathrm{F}_{340} / \mathrm{F}_{380}\right)$ after subtracting autofluorescence recorded prior to dye loading.

\section{Membrane damage}

As an index of myofiber membrane damage, EDL muscles were treated for $1 \mathrm{~h}$ with standard PSS, $1.2 \% \mathrm{BaCl}_{2}$ dissolved in standard PSS, or $1.2 \% \mathrm{BaCl}_{2}$ dissolved in $\mathrm{Ca}^{2+}$ free PSS then stained for $20 \mathrm{~min}$ with membranepermeant Hoechst $33342(1 \mu \mathrm{M}$, Cat. \# H1399, Fisher) and membrane-impermeant propidium iodide (PI; $2 \mu \mathrm{M}$, Cat. \# P4170, Sigma) in PSS. These dyes stain the nuclei of all cells and nuclei of cells with disrupted membranes, respectively [21]. Muscles were then washed for $30 \mathrm{~min}$ in standard PSS and image stacks were acquired with a water immersion objective $(\times 40$; NA $=0.8)$ coupled to a DS-Qi2 camera with Elements software (version 4.51) on an E800 microscope (all from Nikon). Stained nuclei were counted within a defined region of interest (ROI; $300 \times 400 \mu \mathrm{m}$ ) of image stacks using Image $J(\mathrm{NIH})$ to quantify the percentage (\%) of total nuclei stained with PI.

\section{Western blot for all-spectrin degradation}

EDL muscles were secured to approximate in situ length and incubated in either standard PSS or $1.2 \% \mathrm{BaCl}_{2}$ in PSS for $1 \mathrm{~h}$ at $37^{\circ} \mathrm{C}$ then frozen in liquid nitrogen. Following homogenization, protein concentration of the supernatant was quantified with the Bradford method (Cat. \# 5000006; Sigma). Protein concentration of each sample was normalized in $4 \mathrm{x}$ Laemmli sample buffer (Cat. \# 1610747, Bio-Rad; Hercules, CA, USA) containing 5\% dithiothreitol. Samples were loaded on 4-20\% gradient Mini-Protein TGX gels (Bio-Rad) for electrophoresis and transferred to LF-PVDF membranes (Millipore; Burlington, MA). Following $2 \mathrm{~h}$ blocking in 5\% milk, membranes were incubated overnight at $4{ }^{\circ} \mathrm{C}$ and again for $3 \mathrm{~h}$ at $25^{\circ} \mathrm{C}$ in primary antibody raised against aII-spectrin (1:250, Cat. \# sc48382, Santa Cruz; Dallas, TX, USA). A secondary antibody (Alexa Fluor 800 IgG, 1:5000; Cat. \# 926-32,212, Li-Cor Biosciences; Lincoln, NE, USA) was used to quantify protein differences with an Li Cor Odyssey Fc imaging system. Western blots were normalized to total protein according to the recommendations for fluorescent Western blotting [22] using Revert total protein stain (Cat. \# 926-11010, LiCor). The $40 \mathrm{kDa}$ bands correlate with the total protein in each lane and are shown to represent equal protein loading $[23,24]$.

\section{Muscle force}

The EDL was prepared for in situ measurements as described [25]. Briefly, in an anesthetized mouse, a 2-0 suture was placed around the left patellar tendon. The distal tendon of the EDL was isolated, secured in 2-0 suture, and then severed from its insertion. The mouse was placed prone on a plexiglass board and the patellar tendon was secured to a vertical metal peg immobilized in the board. The distal EDL tendon was tied to a load beam (LCL-113G; Omega, Stamford, CT, USA) coupled to a Transbridge amplifier (TBM-4; World Precision Instruments, Sarasota, FL, USA). The load beam was attached to a micrometer for adjusting optimal length $\left(L_{\mathrm{o}}\right)$ as determined during twitch contractions at $1 \mathrm{~Hz}$ [8]. A strip of KimWipe ${ }^{\circ}$ was wrapped around the EDL and $1.2 \% \mathrm{BaCl}_{2}$ irrigated the $\mathrm{EDL}\left(3 \mathrm{~mL} \mathrm{~min}^{-1}\right)$ while resting force was evaluated for $1 \mathrm{~h}$ with Power Lab acquisition software (ADInstruments, Colorado Springs, CO, USA) on a personal computer. 


\section{Neuromuscular junction histology}

In a mouse strain with genetically labeled Schwann cells (S100B-GFP/Kosmos [26]), the TA muscle of one hindlimb was injured with $\mathrm{BaCl}_{2}$ injection and the contralateral limb was left intact. Mice were studied at 0 (control), 1, 2, and 3 dpi. At each time point, the hindlimb was excised, the TA was removed, and myofibers were gently teased apart with fine forceps in ice-cold phosphate-buffered saline (PBS, $\mathrm{pH}$ 7.4) to facilitate antibody penetration. Samples were fixed for $15 \mathrm{~min}$ in $4 \%$ paraformaldehyde, washed in PBS 3 times for $5 \mathrm{~min}$, and stained for neurofilament-heavy (primary antibody: chicken anti-mouse, 1:400; Cat. \# CPCA-NF-H Encor Biotechnology Inc.; Gainesville, FL, USA; secondary antibody: goat anti-chicken, 647 IgY, 1:1000, Cat. \# A21449 , Fisher); each antibody was incubated overnight at $4{ }^{\circ} \mathrm{C}$ followed by washing in PBS 6 times for $30 \mathrm{~min}$. Nicotinic receptors were then stained with $\alpha$-bungarotoxin conjugated to tetramethylrhodamine (1:500, Cat. \# 00014, Biotrend; Koln, Germany) for $2 \mathrm{~h}$ at room temperature and washed in PBS prior to imaging. Images were acquired with a $\times 25$ water immersion objective $(\mathrm{NA}=0.95)$ at $\times 1.75$ digital zoom on an inverted laser scanning confocal microscope (TCS SP8, Leica Microsystems Buffalo Grove, IL, USA) using Leica LAX software. Image stacks (thickness, $\sim 150 \mu \mathrm{m}$ ) were used to resolve NMJ morphology.

\section{Microvessel histology}

The GM was used for histological analysis of skeletal muscle microvasculature based on it being a thin (100$200 \mu \mathrm{m}$ ), planar muscle which facilitates imaging of microvessels throughout the tissue [8]. A GM was dissected away from its origin along the lumbar fascia, sacrum, and iliac crest, reflected away from the body, and spread onto a transparent rubber pedestal. Superficial connective tissue was removed using microdissection and the muscle was severed from its insertion. To image capillary networks, the unfixed GM was immersed in PBS, a small glass block was placed on top to gently flatten the muscle, and image stacks were acquired as described for NMJs. In Cdh5mTmG mice, all endothelial cells are labeled with membrane-localized GFP following tamoxifen-induced Cre recombination.

\section{Data analysis}

Data were analyzed using Student's $t$ test and one-way Analysis of Variance with Bonferroni's multiple comparison test post hoc when appropriate (Prism 5, GraphPad Software, La Jolla, CA, USA). Summary data are presented as means $\pm \mathrm{SEM} ; n$ refers to the number of preparations (each from a different mouse) in a given experimental group. $P \leq 0.05$ was considered statistically significant.

\section{Results}

\section{$\mathrm{BaCl}_{2}$ depolarizes myofibers}

Resting $\mathrm{V}_{\mathrm{m}}$ of EDL myofibers was $\sim-80 \mathrm{mV}$, consistent with previous reports [27-29]. The myofiber sarcolemma contains multiple $\mathrm{K}^{+}$channels, including $\mathrm{K}_{\mathrm{V}}, \mathrm{K}_{\mathrm{IR}}, \mathrm{K}_{\mathrm{Ca}}$, and $\mathrm{K}_{\text {ATP }}$ [30]. Consistent with $\mathrm{BaCl}_{2}$ acting as a broad spectrum $\mathrm{K}^{+}$channel inhibitor [12], the addition of $1.2 \%$ $\mathrm{BaCl}_{2}$ to standard PSS irrigating the muscle depolarized myofibers from $-79 \pm 3 \mathrm{mV}$ at rest to $-17 \pm 7 \mathrm{mV}$ (Fig. 1; $P=0.001$ ). A rapid phase of depolarization occurred within the first 1-2 min followed by a slower phase (Fig. 1a). In some cells, $\mathrm{V}_{\mathrm{m}}$ reached 0 $\mathrm{mV}$ indicating cell death. A similar depolarization was recorded when $\mathrm{BaCl}_{2}$ was substituted isotonically for $\mathrm{NaCl}$ (osmotic control, Fig. $1 b ; P=0.001$ ), illustrating that the effects of $\mathrm{BaCl}_{2}$ were not due to osmotic changes from its addition to PSS. There were no differences in $\Delta \mathrm{V}_{\mathrm{m}}$ (vehicle $62 \pm 5 \mathrm{mV}$, osmotic control $66 \pm 8 \mathrm{mV}$; $P=0.72$ ), or the time course (Fig. $1 c ; P=0.68$ ) between respective solutions containing $1.2 \% \mathrm{BaCl}_{2}$. In the absence of $\mathrm{BaCl}_{2}, \mathrm{~V}_{\mathrm{m}}$ remained stable $(\sim-80 \mathrm{mV})$ for at least $30 \mathrm{~min}(n=3)$.

\section{$\mathrm{BaCl}_{2}$ increases $\left[\mathrm{Ca}^{2+}\right]_{\mathrm{i}}$ and muscle force}

A primary consequence of myofiber depolarization in healthy muscle is internal release of $\mathrm{Ca}^{2+}$ from the sarcoplasmic reticulum (SR) via coupling to L-type $\mathrm{Ca}^{2+}$ channels (i.e., dihydropyridine receptors), which act as voltage sensors in the sarcolemma [31]. The addition of $1.2 \% \mathrm{BaCl}_{2}$ to standard PSS evoked a robust increase in myofiber $\left[\mathrm{Ca}^{2+}\right]_{\mathrm{i}}$ (Fig. $2 a ; P<0.001$ ). Isotonic $\mathrm{BaCl}_{2}$ solution resulted in a similar increase in $\left[\mathrm{Ca}^{2+}\right]_{\mathrm{i}}\left(\mathrm{F}_{340} / \mathrm{F}_{380}\right.$ increased from $1.18 \pm 0.02$ (baseline) to $1.58 \pm 0.06\left(\mathrm{BaCl}_{2}\right)$; $n=3$ ). In contrast, adding $1.2 \% \mathrm{BaCl}_{2}$ to $\mathrm{Ca}^{2+}$-free PSS had no significant effect on $\left[\mathrm{Ca}^{2+}\right]_{\mathrm{i}}$ (Fig. 2a). In the absence of $\mathrm{BaCl}_{2}$, Fura 2 fluorescence remained stable at the resting baseline for at least $30 \mathrm{~min}(n=3)$.

Irrigating the $\mathrm{EDL}$ in situ with $1.2 \% \mathrm{BaCl}_{2}$ in standard PSS increased resting force from $7.4 \pm 0.1$ to $11.1 \pm 0.4 \mathrm{~g}$ over $\sim 30 \mathrm{~min}$, which then returned to baseline during the $60 \mathrm{~min}$ exposure (Fig. $2 b ; P=0.001$ ). Whereas a rise in $\left[\mathrm{Ca}^{2+}\right]_{\mathrm{i}}$ activates the contractile proteins [32], sustained elevation of $\left[\mathrm{Ca}^{2+}\right]_{\mathrm{i}}$ stimulates mitochondrial production of reactive oxygen species (ROS), which can impair cross-bridge function [33]. $\mathrm{Ca}^{2+}$-activated proteolysis disrupts the integrity of contractile proteins [15], which we surmise may have occurred in the present experiments.

\section{$\mathrm{BaCl}_{2}$ activates proteolysis and disrupts membranes}

Elevating $\left[\mathrm{Ca}^{2+}\right]_{\mathrm{i}}$ leads to degradation of muscle fibers through proteolysis by $\mathrm{Ca}^{2+}$-activated neutral proteases $[15,16]$. For example, calpain is activated in two primary steps: (1) the inactive enzyme translocates to the 

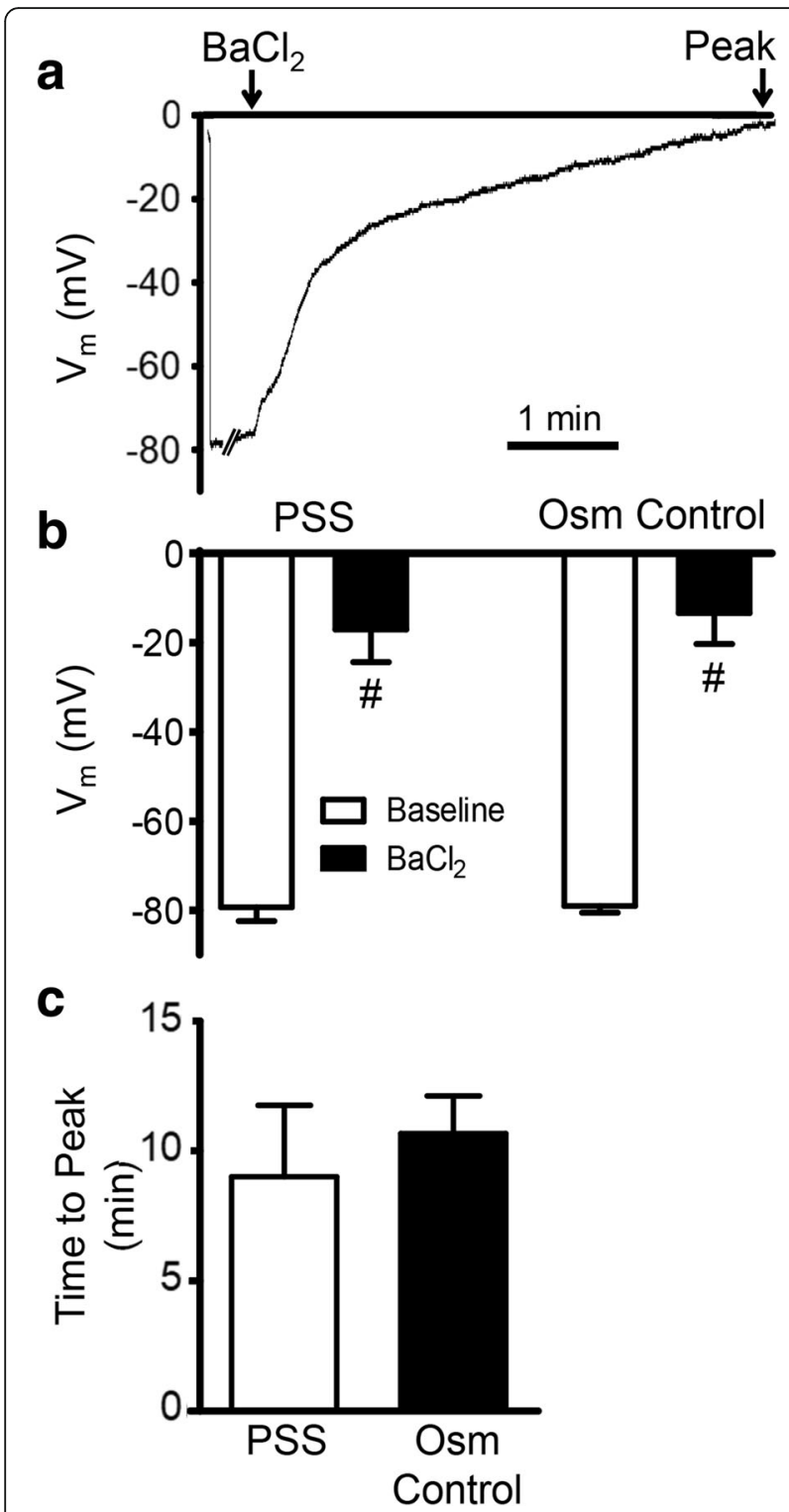

Fig. $1 \mathrm{BaCl}_{2}$ depolarizes skeletal muscle myofibers. a Representative continuous recording of $V_{m}$ illustrates depolarization of mouse EDL myofiber upon exposure to $1.2 \% \mathrm{BaCl}_{2}$. b Summary data for $V_{m}$ are at resting baseline, at peak depolarization during $1.2 \% \mathrm{BaCl}_{2}$ added to standard PSS and to PSS in which $\mathrm{BaCl}_{2}$ replaced $\mathrm{NaCl}$ for osmotic (Osm) control. c Summary data for time to peak depolarization during $1.2 \% \mathrm{BaCl}_{2}$ added to standard PSS, and to PSS in which $\mathrm{BaCl}_{2}$ replaced $\mathrm{NaCl}$ for Osm control. Values are means \pm SEM ( $n=3-6$ myofibers, each from one EDL muscle per mouse). ${ }^{\#} P \leq 0.05$ vs. baseline

sarcolemma where the $\mathrm{N}$-terminus is cleaved through autolysis releasing active calpain, and (2) two $\mathrm{Ca}^{2+}$ ions bind to the protease domain to maintain the active site [34]. Active calpain cleaves skeletal muscle structural proteins including titan, nebulin, and $\alpha$ II-spectrin [35]. In EDL muscles exposed to $1.2 \% \mathrm{BaCl}_{2}$ in standard PSS for $1 \mathrm{~h}, \alpha \mathrm{II}$-spectrin was cleaved from 240 to a $150 \mathrm{kDa}$ product (Fig. 3; $P=0.02$ ), which was accompanied by an increase in the ratio of cleaved: total $\alpha$ II-spectrin (control $\left.=2.8 \pm 1.25 ; \mathrm{BaCl}_{2}=17.9 \pm 8.9(P=0.12, n=6)\right)$.

Myonuclei in EDL muscles treated with PSS exhibited minimal PI staining after $1 \mathrm{~h}(8 \%)$ while nearly all myonuclei $(92 \%)$ were stained following $1 \mathrm{~h}$ of exposure to $1.2 \% \mathrm{BaCl}_{2}$, thus indicating gross disruption of sarcolemma throughout the muscle (Fig. 4; $P<0.001$ ). Removal of $\mathrm{Ca}^{2+}$ from the irrigation solution prevented the incorporation of PI, demonstrating the importance of $\mathrm{Ca}^{2+}$ influx from the extracellular fluid in $\mathrm{BaCl}_{2}$-induced membrane disruption (Fig. $4 c ; P<0.0001$ ). $\mathrm{Ca}^{2+}$-activated calpain can stimulate several proapoptotic pathways. While calpain-activated caspase 12 promotes apoptosis through the "executioner" caspase 3 [36, 37], it can also cleave BH3-only protein (Bid) and apoptosisinducing factor (AIF) to truncated Bid and truncated AIF, thereby causing mitochondrial membrane permeability and ensuing apoptosis [38].

\section{$\mathrm{BaCl}_{2}$ induces injury of motor axons and microvessels} In contrast to the integrity of pre- and postsynaptic elements characteristic of healthy NMJs, neurofilamentheavy staining at $1 \mathrm{dpi}$ appeared fragmented, suggesting axonal disruption. Clusters of acetylcholine receptors also became dispersed along the laminar surface and Schwann cells began to migrate away from the NMJ, which progressed through 2 dpi (Fig. $5 a$ ). By 3 dpi, Schwann cells appear to associate with axonal fragments and AChR clusters. These data demonstrate that motor axons in the vicinity of $\mathrm{BaCl}_{2}$ injection undergo degeneration within $24 \mathrm{~h}$ that extends over 3 days, consistent with the time course of Schwann cell migration following axotomy [39].

Uninjured muscle exhibits an orderly network of capillaries (Fig. 5b). Following $\mathrm{BaCl}_{2}$ injury, capillaries were fragmented at $1 \mathrm{dpi}$. By $3 \mathrm{dpi}$, anastomoses (interconnecting loops) began to appear between capillary sprouts. While these observations add new insight to the extent of tissue injury induced by $\mathrm{BaCl}_{2}$, our findings are consistent with structural damage of microvessels induced by $\mathrm{BaCl}_{2}$ at $2 \mathrm{dpi}$ [3] and our recent report that capillary perfusion was disrupted at $1 \mathrm{dpi}[8]$.

\section{Discussion}

Skeletal muscle comprises $\sim 40 \%$ of body mass and has the remarkable ability to regenerate following injury due to resident satellite cells. Skeletal muscle injuries occur in multiple ways including disease, physical trauma, temperature extremes, eccentric contractions, and exposure to myotoxic agents [3-5]. Whereas myofibers follow a similar pattern of regeneration irrespective of the mechanism of injury $[1,40]$, the kinetics and involvement of satellite cells can vary with the nature of insult 


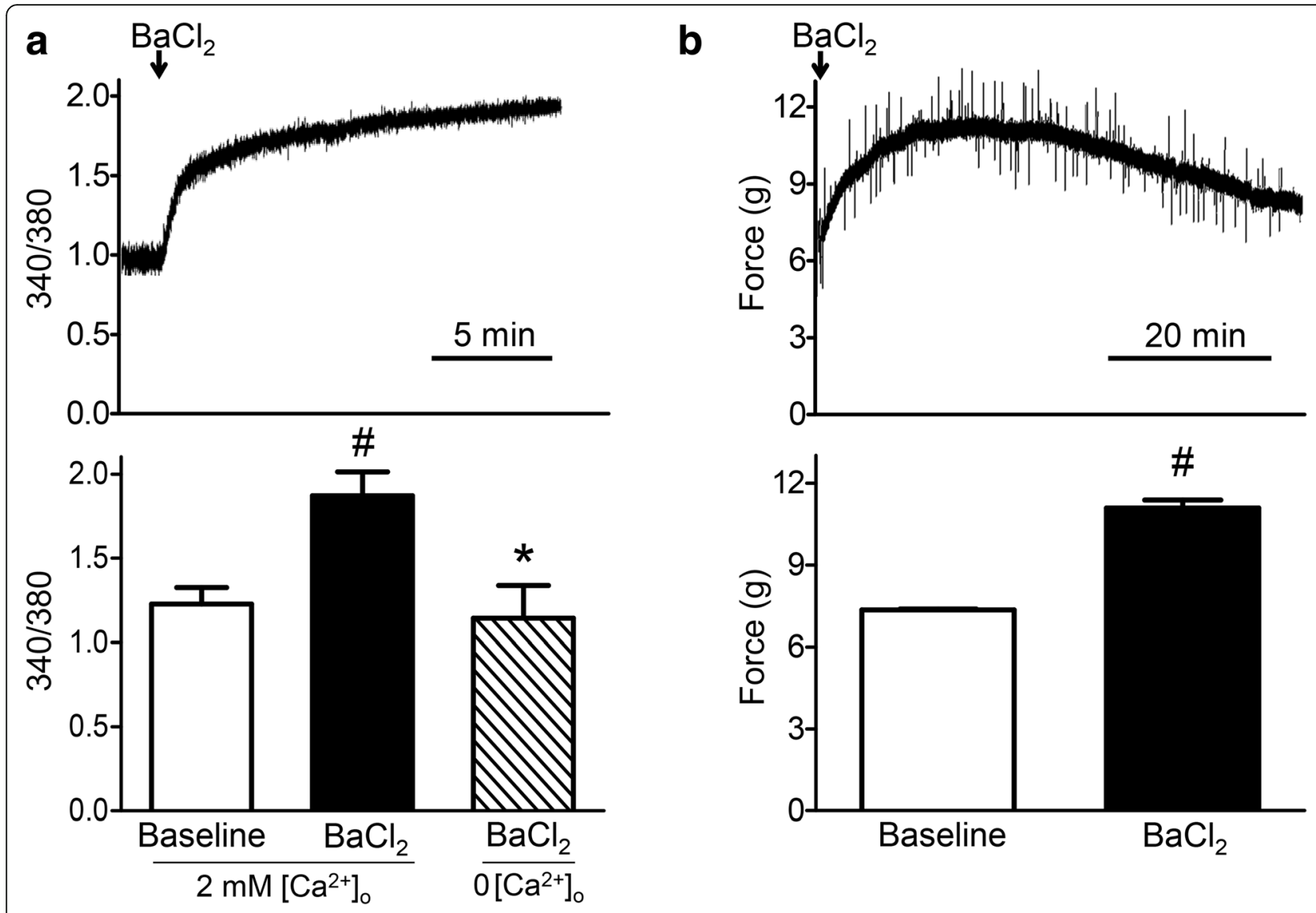

Fig. $2 \mathrm{BaCl}_{2}$ increases $\left[\mathrm{Ca}^{2+}\right]_{i}$ and muscle force. a Top: representative continuous recording of $\mathrm{F}_{340} / \mathrm{F}_{380}$ illustrates intracellular $\mathrm{Ca}^{2+}$ accumulation. Bottom: summary data for $\mathrm{F}_{340} / \mathrm{F}_{380}$ at rest (baseline) and during peak response to $1.2 \% \mathrm{BaCl}_{2}$ in PSS $(n=5)$ and $1.2 \% \mathrm{BaCl}_{2}$ in $\mathrm{Ca}^{2+}$-free PSS $(0$ $\left.\left[\mathrm{Ca}^{2+}\right]_{0}\right)(n=3)$. $\mathbf{b}$ Top: representative continuous recording of force developed by EDL in situ at optimum resting length $\left(L_{0}\right)$ in response to irrigation with $1.2 \% \mathrm{BaCl}_{2}$ for $1 \mathrm{~h}$. Bottom: summary data for resting and peak force in response to $1.2 \% \mathrm{BaCl}_{2}$; values are means $\pm \mathrm{SEM}(n=4$ muscles). ${ }^{\#} P \leq 0.05$ vs. baseline, ${ }^{*} P \leq 0.05$ vs. $1.2 \% \mathrm{BaCl}_{2}$ in standard PSS with $2 \mathrm{mM}$ extracellular calcium concentration $\left(\left[\mathrm{Ca}^{2+}\right]_{0}\right)$

[3]. For example, freeze injury results in a dead zone of tissue that viable cells must penetrate, whereas local exposure to $\mathrm{BaCl}_{2}$ induces coordinated necrosis of myofibers with infiltration of inflammatory cells followed by sequential regeneration of myofibers [1, 3].

Unlike freeze damage, $\mathrm{BaCl}_{2}$-induced injury preserves satellite cells, which allows detailed examination of their gene expression, cell signaling, and regeneration kinetics in vivo. Remarkably, how $\mathrm{BaCl}_{2}$ kills myofibers has remained undefined. In accord with the ability of $\mathrm{Ba}^{2+}$ to block $\mathrm{K}^{+}$channels $[11,12]$, we reasoned that it would depolarize myofibers, as the sarcolemma contains $\mathrm{K}_{\mathrm{V}}$, $K_{I R}, K_{C a}$ and $K_{A T P}$ channels [30]. The progression of depolarization we observed in EDL may reflect reliance on $\mathrm{Cl}^{-}$conductance for resting $\mathrm{V}_{\mathrm{m}}$ in skeletal muscle, which can buffer the abrupt effect of changing the conductance of other ions [41]. Following $\mathrm{BaCl}_{2}$-induced depolarization, the present data show that increasing $\left[\mathrm{Ca}^{2+}\right]_{\mathrm{i}}$ leads to proteolysis, membrane disruption, and myofiber death. Moreover, preventing the rise of
$\left[\mathrm{Ca}^{2+}\right]_{\mathrm{i}}$ by removing extracellular $\mathrm{Ca}^{2+}$ preserves membrane integrity as demonstrated by the paucity of myonuclei stained with PI under this condition (Fig. 4c). Myotoxicity through $\mathrm{Ca}^{2+}$-mediated proteolysis and membrane disruption subsequent to $\mathrm{Ba}^{2+}$ exposure is consistent with the action of biological agents known to disrupt myofibers such as bee, wasp, and snake venoms [42-44].

$\mathrm{BaCl}_{2}$ has been used to study the pathophysiology of hypokalemia, a clinical condition which depolarizes muscle fibers through reduced $\mathrm{K}^{+}$efflux $[10,45]$. In hypokalemia, the SR is integral to myofiber disruption [10, $46,47]$, with $\mathrm{Ca}^{2+}$ release from internal stores being a primary source of the elevated $\left[\mathrm{Ca}^{2+}\right]_{i}$ that contributes to muscle injury. While the relative contribution of $\mathrm{Ca}^{2+}$ release from internal stores vs. influx through L-type channels during $\mathrm{BaCl}_{2}$ injury remains to be determined, the SR is the principal source of elevating $\left[\mathrm{Ca}^{2+}\right]_{\mathrm{i}}$ during muscle contractions [48]. Consistent with this effect, we observed transient contraction of the EDL upon exposure to $\mathrm{BaCl}_{2}$ 

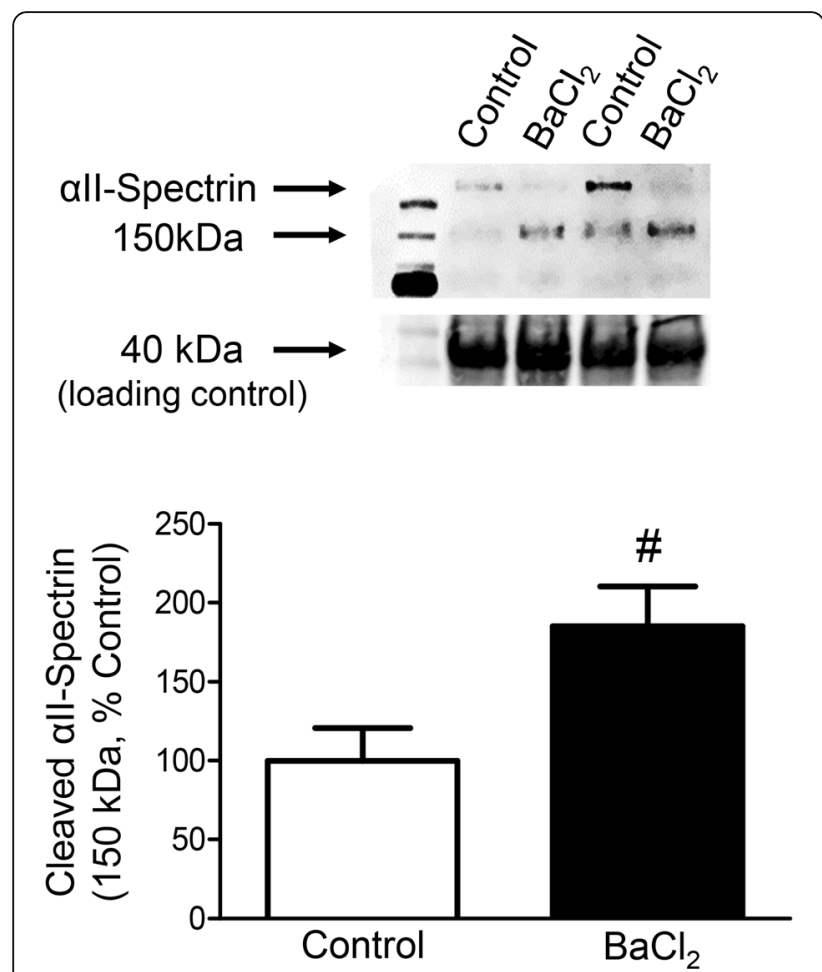

Fig. $3 \mathrm{BaCl}_{2}$ increases calpain activity. Representative Western blots (top) and mean densitometric data (bottom) for all-spectrin from EDL muscles treated with standard PSS (Control) or $1.2 \% \mathrm{BaCl}_{2}$ in standard PSS for $1 \mathrm{~h}$. The all-spectrin band at $240 \mathrm{kDa}$ and its cleavage product at $150 \mathrm{kDa}$ were both normalized to total protein reflected by the $40 \mathrm{kDa}$ band, which was not different between samples. Summary data are means \pm SEM ( $n=6$ muscles). ${ }^{\#} P \leq 0.05$ vs. control that peaked with the rise in $\left[\mathrm{Ca}^{2+}\right]_{\mathrm{i}}$ over $20-30 \mathrm{~min}$ (Fig. 2). The recovery to resting (passive) tension during the ensuing $30 \mathrm{~min}$ may reflect disruption of the contractile machinery. This interpretation is consistent with the degradation of $\alpha$ II-spectrin we observed within $60 \mathrm{~min}$ of $\mathrm{BaCl}_{2}$ exposure (Fig. 3). Once in the cytoplasm, $\mathrm{Ba}^{2+}$ can enter mitochondria [49] and generate superoxide by increasing electron flow from $\mathrm{Ca}^{2+}$-sensitive citric acid cycle dehydrogenases and thereby dissipate mitochondrial membrane potential [50]. The ensuing disruption of mitochondria releases cytochrome $\mathrm{C}$ into the cytosol to initiate intrinsic apoptosis, culminating in the activation of caspase 3 and cell death [36].

\section{Nerve and microvessel injury}

Motor nerves and microvessels control and supply myofibers of intact skeletal muscle by initiating contraction and delivering nutrients in response to metabolic demand [51]. Given their intimate physical proximity and shared signaling events, we hypothesized that muscle injury induced by $\mathrm{BaCl}_{2}$ would disrupt motor axons and capillaries. Similar to the time course of myofiber disruption [3], the present data illustrate that motor nerves and microvessels appear fragmented within $24 \mathrm{~h}$ following local injection of $\mathrm{BaCl}_{2}$ (Fig. 5).

It is unclear whether nerves and capillaries undergo damage directly from $\mathrm{BaCl}_{2}$ or indirectly as a secondary effect of myofiber disruption. Mechanical changes within the injured myofiber can lead to degeneration of the NMJ. For example, with local injury, myofilaments contract on both sides of the injured site, leaving an empty tube with partially retracted nerve terminals juxtaposed

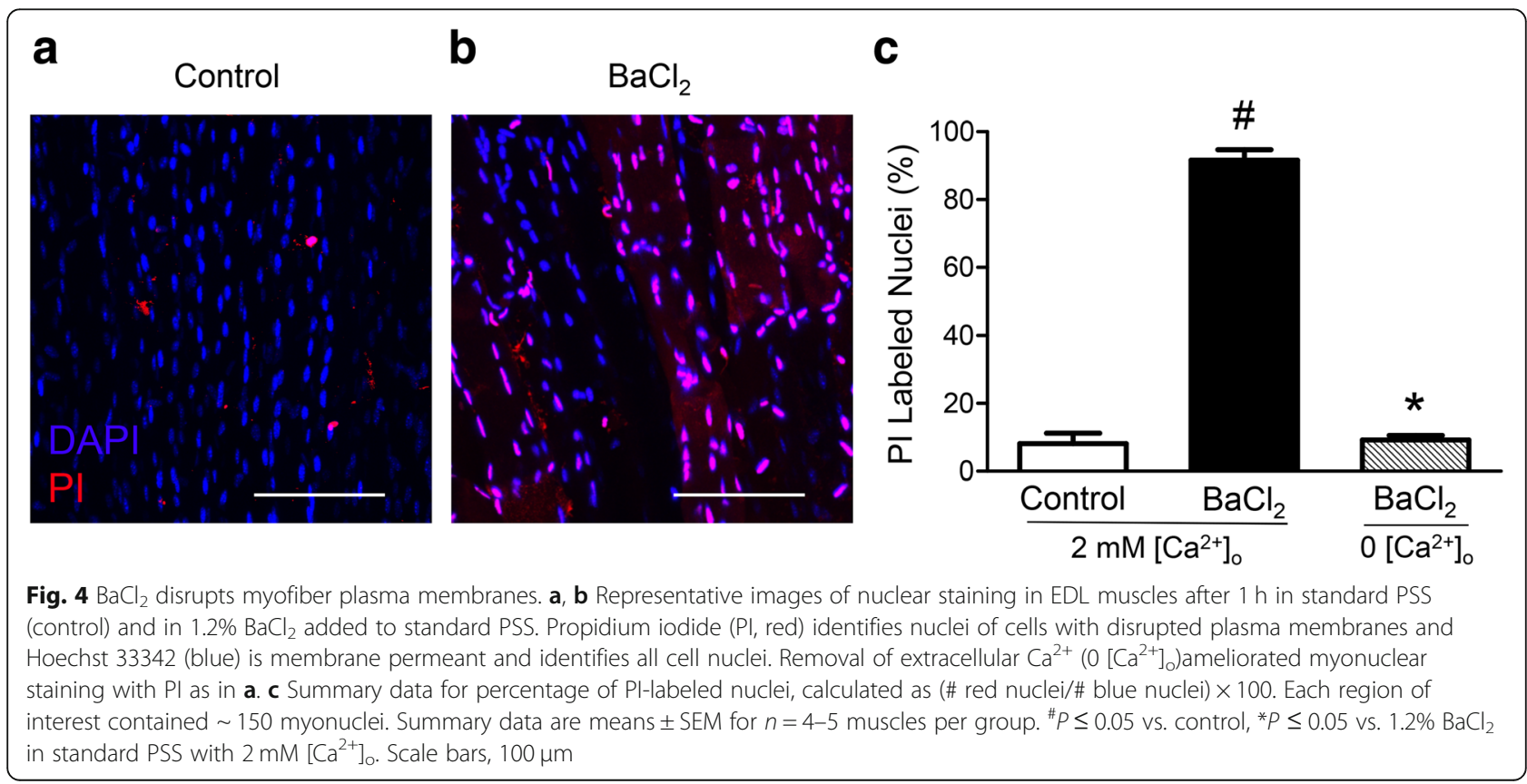




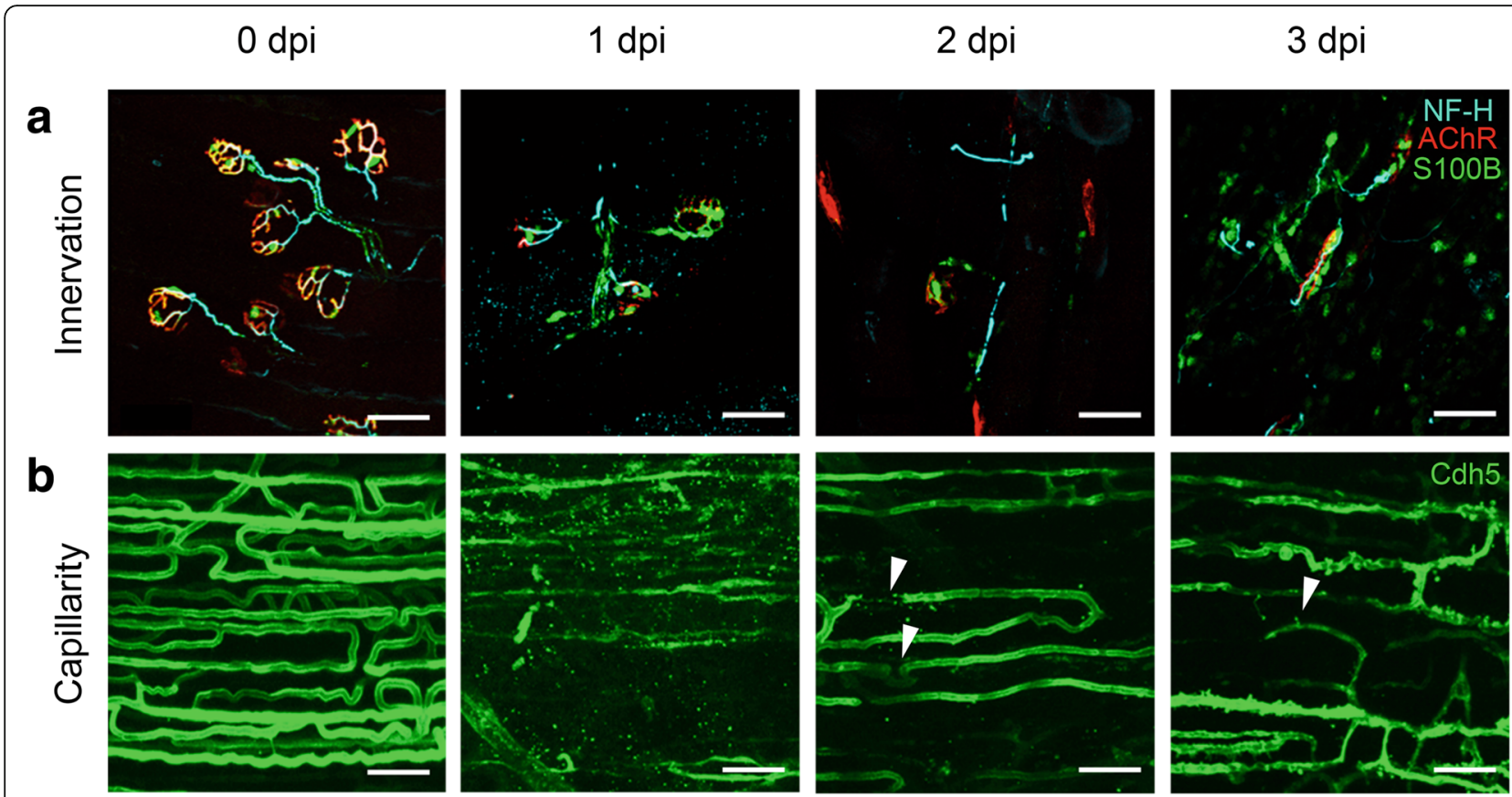

Fig. 5 Motor innervation and capillaries are disrupted by local $\mathrm{BaCl}_{2}$ injection. a Neuromuscular junctions in TA muscle. Schwann cells (green) are closely associated with axonal neurofilament-heavy (cyan; indicates motor axons) and overlay postsynaptic nicotinic receptors (red) at 0 dpi (uninjured control). Following injection of $1.2 \% \mathrm{BaCl}_{2}, \mathrm{NMJ}$ components are dissociating at 1 dpi and fragmented at 2 and 3 dpi. b Capillaries in GM (green endothelial cells) are densely organized and align along myofibers in uninjured muscle ( 0 dpi). Following injection of $1.2 \% \mathrm{BaCl}_{2}$, disrupted and fragmented capillaries are observed at 1-2 dpi (arrowheads) while evidence of capillary neoformation is apparent at $3 \mathrm{dpi}$ (arrowhead). Scale bars, $50 \mu \mathrm{m}$. Color coding in $3 \mathrm{dpi}$ panels applies to earlier timepoints for innervation and capillarity. NF-H, neurofilament heavy; AChR, nicotinic actetylcholine receptors; S100B, Schwann cells expressing GFP; Cdh5, endothelial cells expressing GFP

to the site [52]. While mechanisms of axon retraction remain to be defined, the change in cell shape suggests that it is a consequence of cytoskeletal remodeling in response to a retraction program or loss of the ability to maintain the cytoskeleton [53]. Because it is a cytoskeletal protein integral to the structure of cell membranes, degradation of $\alpha \mathrm{II}$-spectrin is disruptive to the sarcolemma and contributes to fragmentation of motor nerve synapses with dissolution of AChR clusters (Fig. 5).

Disruption of capillaries occurs in multiple models of muscle injury [3]. The present data are the first to illustrate that these events coincide with the loss of neuromuscular integrity. Thus, key elements of myofiber control and supply are similarly affected, with loss of structural integrity occurring during the initial $24 \mathrm{~h} \mathrm{(1}$ dpi) and initial stages of recovery apparent at $3 \mathrm{dpi}$. In addition to myofibers, vessels and nerves may undergo calpain-dependent degradation [54, 55]. Thus, while skeletal muscle consists primarily of myofibers, the increase in calpain-specific $\alpha$ II-spectrin degradation measured in our homogenates (Fig. 3) may be derived from multiple cell types. As we have observed directly with intravital microscopy in the GM, the inflammatory response to $\mathrm{BaCl}_{2}$ begins within $1-2 \mathrm{~h}$ of exposure (Fernando and Segal, unpublished observations from
[8]). Infiltration of the tissue with neutrophils, monocytes, and pro-inflammatory macrophages ensues over the next 2-3 days, thereby disrupting all tissue components indiscriminately $[3,56]$ through activation of additional proteolytic pathways and oxidative modification of proteins to accelerate proteolysis [36].

\section{Conclusion}

Skeletal muscle injury induced by $\mathrm{BaCl}_{2}$ is widely used as a method for studying myofiber damage and regeneration [3, 6-9]. Because the mechanism of $\mathrm{BaCl}_{2}$-induced injury was unknown, the goal of the present study was to define the nature of myofiber damage and ascertain whether associated tissue elements were similarly affected. Using complementary ex vivo preparations of skeletal muscle, we demonstrate that acute exposure to $\mathrm{BaCl}_{2}$ causes myofiber damage via $\mathrm{Ca}^{2+}$-dependent proteolysis secondary to membrane depolarization. Further, motor axons and microvessels appear to undergo damage with a similar time course to the disruption of myofibers. These data provide a foundation for investigating how major tissue components responsible for skeletal muscle structure and function (i.e., myofibers, motor nerves, and microvessels) respond to and interact during muscle injury and regeneration. 


\section{Supplementary information}

Supplementary information accompanies this paper at https://doi.org/10. 1186/s13395-019-0213-2.

Additional file 1. Satellite cells are spared from $\mathrm{BaCl}_{2}$-induced death in vitro. Treatment with $\mathrm{BaCl}_{2}$ in vivo is used to induce myofiber damage leading to satellite cell activation and muscle regeneration. To formally demonstrate the differential effects of $\mathrm{BaCl}_{2}$ on myofibers and their associated satellite cells, we isolated single muscle fibers from the EDL muscle and exposed them to either saline or $1.2 \% \mathrm{BaCl}_{2}$ in the presence of propidium iodide (PI) to label nuclei with disrupted laminae (dead or dying). Fibers were fixed in $4 \%$ paraformaldehyde then stained for expression of the satellite cell marker CD34 (rat monoclonal RAM-34, eBioscience at 1:200) (arrows). Myofibers fixed at $0 \mathrm{~min}(A)$ or after $50 \mathrm{~min}$ in $\mathrm{Ca}^{2+}, \mathrm{Mg}^{2+}$-free PBS $(B)$ retain their morphology and integrity and do not incorporate PI in either satellite cell nuclei or myonuclei. In contrast, myofibers exposed to $1.2 \% \mathrm{BaCl}_{2}$ for 50 min (C) have hypercontracted, lost their structural integrity, and possess PI-labeled nuclei. However, satellite cells associated with these fibers have not incorporated PI. D, Addition of $1.2 \% \mathrm{BaCl}_{2}$ to isolated single fibers leads to elevated $\left[\mathrm{Ca}^{2+}\right]_{\text {; }}$ as observed in whole-muscle preparations (Fig. 2). The severity and kinetics of $\mathrm{BaCl}_{2}$-induced myotoxicity for single fibers appear to be less than observed in our experiments using whole muscles. We hypothesize that the absence of fixed attachments at the ends of single myofibers may reduce the damaging membrane stress following $\mathrm{Ca}^{2+}$-induced hypercontraction. Scale bars $=10 \mu \mathrm{m}$.

\section{Abbreviations}

$\left[\mathrm{Ca}^{2+}\right]_{\mathrm{i}}$ : Intracellular calcium concentration; $\left[\mathrm{Ca}^{2+}\right]_{0}$ : Extracellular calcium concentration; AChR: Acetylcholine receptors; AlF: Apoptosis-inducing factor;

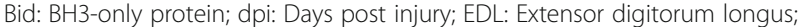
EGTA: Ethylene glycol-bis ( $\beta$-aminoethyl ether)-N,N,N',N'-tetraacetic acid; GFP: Green fluorescent protein; GM: Gluteus maximus; IgG: Immunoglobulin G; NMJ: Neuromuscular junction; PBS: Phosphate-buffered saline; PSS: Physiological salt solution; ROI: Region of interest; TA: Tibialis anterior; $V_{m}$ : Membrane potential

\section{Authors' contributions}

ABM and CEN share equal contribution to the experimental design, data acquisition and analysis, and drafting of the manuscript. NLJ assisted with the data acquisition and interpretation. CAF, DDWC, and SSS contributed to the conception and design of the experiments, interpretation of the data, and revision of the manuscript. All authors read and approved the final manuscript for publication.

\section{Funding}

The study was supported by a Margaret Proctor Mulligan Professorship and a R37HL041026 to SSS from the National Institutes of Health; DDWC was supported by NIH R01AR067450.

\section{Availability of data and materials}

The datasets used and/or analyzed during the current study are available from the corresponding author on reasonable request. Materials used in this study are commercially available.

\section{Ethics approval and consent to participate}

All procedures were approved by the Animal Care and Use Committee of the University of Missouri, Columbia (protocol reference no. 9220) and were performed in accord with the National Research Council's Guide for the Care and Use of Laboratory Animals (2011).

\section{Consent for publication}

Not applicable

\section{Competing interests}

The authors declare that they have no competing interests.

\section{Author details}

'Department of Medical Pharmacology and Physiology, University of Missouri, MA415 Medical Sciences Building, 1 Hospital Drive, Columbia, MO
65212, USA. ²Division of Biological Sciences and Christopher S. Bond Life Sciences Center, University of Missouri, Columbia, MO 65201, USA. ${ }^{3}$ Dalton Cardiovascular Research Center, Columbia, MO 65211, USA.

Received: 11 July 2019 Accepted: 30 September 2019

Published online: 06 November 2019

\section{References}

1. Tidball JG. Mechanisms of muscle injury, repair, and regeneration. Compr Physiol. 2011;1(4):2029-62.

2. Carosio S, Berardinelli MG, Aucello M, Musaro A. Impact of ageing on muscle cell regeneration. Ageing Res Rev. 2011;10(1):35-42.

3. Hardy D, Besnard A, Latil M, Jouvion G, Briand D, Thepenier C, et al. Comparative study of injury models for studying muscle regeneration in mice. PLoS One. 2016:11(1):e0147198.

4. Tabebordbar M, Wang ET, Wagers AJ. Skeletal muscle degenerative diseases and strategies for therapeutic muscle repair. Annu Rev Pathol. 2013:8:441-75.

5. Benoit PW, Belt WD. Destruction and regeneration of skeletal muscle after treatment with a local anaesthetic, bupivacaine (Marcaine). J Anat. 1970; 107(Pt 3):547-56.

6. Tierney MT, Sacco A. Inducing and evaluating skeletal muscle injury by notexin and barium chloride. Methods Mol Biol. 2016;1460:53-60.

7. Casar JC, McKechnie BA, Fallon JR, Young MF, Brandan E. Transient upregulation of biglycan during skeletal muscle regeneration: delayed fiber growth along with decorin increase in biglycan-deficient mice. Dev Biol. 2004;268(2):358-71.

8. Fernando CA, Pangan AM, Cornelison D, Segal SS. Recovery of blood flow regulation in microvascular resistance networks during regeneration of mouse gluteus maximus muscle. J Physiol. 2019;597(5):1401-17.

9. Cornelison DD, Wilcox-Adelman SA, Goetinck PF, Rauvala H, Rapraeger AC, Olwin BB. Essential and separable roles for Syndecan-3 and Syndecan-4 in skeletal muscle development and regeneration. Genes Dev. 2004;18(18):2231-6.

10. Gallant EM. Barium-treated mammalian skeletal muscle: similarities to hypokalaemic periodic paralysis. J Physiol. 1983;335:577-90.

11. Bonev AD, Nelson MT. ATP-sensitive potassium channels in smooth muscle cells from Guinea pig urinary bladder. Am J Phys. 1993;264(5 Pt 1):C1190-200.

12. Nelson MT, Quayle JM. Physiological roles and properties of potassium channels in arterial smooth muscle. Am J Phys. 1995:268(4 Pt 1):C799-822.

13. Flucher BE, Tuluc P. How and why are calcium currents curtailed in the skeletal muscle voltage-gated calcium channels? J Physiol. 2017;595(5): 1451-63.

14. Cho $\mathrm{CH}$, Woo JS, Perez CF, Lee EH. A focus on extracellular $\mathrm{Ca}^{2+}$ entry into skeletal muscle. Exp Mol Med. 2017:49(9):e378.

15. Turner PR, Westwood T, Regen CM, Steinhardt RA. Increased protein degradation results from elevated free calcium levels found in muscle from mdx mice. Nature. 1988;335(6192):735-8.

16. Duncan CJ. Role of intracellular calcium in promoting muscle damage: a strategy for controlling the dystrophic condition. Experientia. 1978; 34(12):1531-5.

17. Nishimune $H$, Shigemoto K. Practical anatomy of the neuromuscular junction in health and disease. Neurol Clin. 2018;36(2):231-40.

18. Segal SS. Regulation of blood flow in the microcirculation. Microcirculation. 2005;12(1):33-45.

19. Wang Y, Nakayama M, Pitulescu ME, Schmidt TS, Bochenek ML, Sakakibara A, et al. Ephrin-B2 controls VEGF-induced angiogenesis and lymphangiogenesis. Nature. 2010;465(7297):483-6.

20. Norton CE, Segal SS. Calcitonin gene-related peptide hyperpolarizes mouse pulmonary artery endothelial tubes through $\mathrm{K}_{\text {ATP }}$ channel activation. Am J Physiol Lung Cell Mol Physiol. 2018;315(2):L212-L26.

21. Norton CE, Sinkler SY, Jacobsen NL, Segal SS. Advanced age protects resistance arteries of mouse skeletal muscle from oxidative stress through attenuating apoptosis induced by hydrogen peroxide. J Physiol. 2019;15: 3801-16.

22. Eaton SL, Roche SL, Llavero Hurtado M, Oldknow KJ, Farquharson C, Gillingwater $\mathrm{TH}$, et al. Total protein analysis as a reliable loading control for quantitative fluorescent Western blotting. PLoS One. 2013;8(8):e72457.

23. Ahn B, Beharry AW, Frye GS, Judge AR, Ferreira LF NAD(P) H oxidase subunit $\mathrm{p} 47^{\text {phox }}$ is elevated, and $\mathrm{p} 47^{\text {phox }}$ knockout prevents diaphragm 
contractile dysfunction in heart failure. Am J Physiol Lung Cell Mol Physiol. 2015;309(5):L497-505.

24. Morton AB, Smuder AJ, Wiggs MP, Hall SE, Ahn B, Hinkley JM, et al. Increased SOD2 in the diaphragm contributes to exercise-induced protection against ventilator-induced diaphragm dysfunction. Redox Biol. 2018:20:402-13.

25. Hakim CH, Wasala NB, Duan D. Evaluation of muscle function of the extensor digitorum longus muscle ex vivo and tibialis anterior muscle in situ in mice. J Vis Exp. 2013;72. https://doi.org/10.3791/50183.

26. Zuo Y, Lubischer J, Kang H, Tian L, Mikesh M, Marks A, et al. Fluorescent proteins expressed in mouse transgenic lines mark subsets of glia, neurons, macrophages, and dendritic cells for vital examination. J Neurosci. 2004;24(49):10999-1009.

27. Harris JB. The resting membrane potential of fibres of fast and slow twitch muscles in normal and dystrophic mice. J Neurol Sci. 1971;12(1):45-52.

28. Mathes C, Bezanilla F, Weiss RE. Sodium current and membrane potential in EDL muscle fibers from normal and dystrophic (mdx) mice. Am J Physiol. 1991;261 (4 Pt 1):C718-25.

29. Yensen C, Matar W, Renaud JM. $\mathrm{K}^{+}$-induced twitch potentiation is not due to longer action potential. Am J Physiol Cell Physiol. 2002;283(1):C169-77.

30. Maqoud F, Cetrone M, Mele A, Tricarico D. Molecular structure and function of big calcium-activated potassium channels in skeletal muscle: pharmacological perspectives. Physiol Genomics. 2017;49(6):306-17.

31. Laver DR. Regulation of the RyR channel gating by $\mathrm{Ca}^{2+}$ and $\mathrm{Mg}^{2+}$. Biophys Rev. 2018;10(4):1087-95.

32. Berchtold MW, Brinkmeier $\mathrm{H}$, Müntener M. Calcium ion in skeletal muscle: its crucial role for muscle function, plasticity, and disease. Physiol Rev. 2000; 80(3):1215-65.

33. Powers SK, Ji LL, Kavazis AN, Jackson MJ. Reactive oxygen species: impact on skeletal muscle. Compr Physiol. 2011;1(2):941-69.

34. Huang J, Zhu X. The molecular mechanisms of calpains action on skeletal muscle atrophy. Physiol Res. 2016;65(4):547-60.

35. Goll DE, Thompson VF, Li H, Wei W, Cong J. The calpain system. Physiol Rev. 2003;83(3):731-801.

36. Powers SK, Morton AB, Ahn B, Smuder AJ. Redox control of skeletal muscle atrophy. Free Radic Biol Med. 2016;98:208-17.

37. Jin Z, El-Deiry WS. Overview of cell death signaling pathways. Cancer Biol Ther. 2005:4(2):139-63.

38. Cheng SY, Wang SC, Lei M, Wang Z, Xiong K. Regulatory role of calpain in neuronal death. Neural Regen Res. 2018;13(3):556-62.

39. Torigoe K, Tanaka HF, Takahashi A, Awaya A, Hashimoto K. Basic behavior of migratory Schwann cells in peripheral nerve regeneration. Exp Neurol. 1996; 137(2):301-8.

40. Karalaki M, Fili S, Philippou A, Koutsilieris M. Muscle regeneration: cellular and molecular events. In Vivo. 2009:23(5):779-96.

41. Wallinga W, Meijer SL, Alberink MJ, Vliek M, Wienk ED, Ypey DL. Modelling action potentials and membrane currents of mammalian skeletal muscle fibres in coherence with potassium concentration changes in the T-tubular system. Eur Biophys J. 1999;28(4):317-29.

42. Ownby CL, Cameron D, Tu AT. Isolation of myotoxic component from rattlesnake (Crotalus viridis viridis) venom. Electron microscopic analysis of muscle damage. Am J Pathol. 1976;85(1):149-66.

43. Habermann E. Bee and wasp venoms. Science. 1972;177(4046):314-22.

44. Harris JB, Cullen MJ. Muscle necrosis caused by snake venoms and toxins. Electron Microsc Rev. 1990;3(2):183-211.

45. Bhoelan BS, Stevering $\mathrm{CH}$, van der Boog AT, van der Heyden MA. Barium toxicity and the role of the potassium inward rectifier current. Clin Toxicol (Phila). 2014;52(6):584-93.

46. López JR, Rojas B, Gonzalez MA, Terzic A. Myoplasmic Ca ${ }^{2+}$ concentration during exertional rhabdomyolysis. Lancet. 1995;345(8947):424-5.

47. Trewby PN, Rutter MD, Earl UM, Sattar MA. Teapot myositis. Lancet. 1998; 351(9111):1248.

48. Flucher BE. How is SR calcium release in muscle modulated by PIP $(4,5)_{2}$ ? J Gen Physiol. 2015;145(5):361-4.

49. Howell SL, Tyhurst M. Barium accumulation in rat pancreatic B cells. J Cell Sci. 1976;22(2):455-65.

50. Powers SK, Wiggs MP, Duarte JA, Zergeroglu AM, Demirel HA. Mitochondrial signaling contributes to disuse muscle atrophy. Am J Physiol Endocrinol Metab. 2012;303(1):E31-9.

51. VanTeeffelen JW, Segal SS. Effect of motor unit recruitment on functional vasodilatation in hamster retractor muscle. J Physiol. 2000;524(Pt 1):267-78.
52. van Mier $\mathrm{P}$, Lichtman J. Regenerating muscle fibers induce directional sprouting from nearby nerve terminals: studies in living mice. J Neurosci. 1994;14(9):5672-86.

53. Luo L, O'Leary DD. Axon retraction and degeneration in development and disease. Annu Rev Neurosci. 2005;28:127-56.

54. Girouard MP, Bueno M, Julian V, Drake S, Byrne AB, Fournier AE. The molecular interplay between axon degeneration and regeneration. Dev Neurobiol. 2018;78(10):978-90.

55. Zhang Y, Liu NM, Wang Y, Youn JY, Cai H. Endothelial cell calpain as a critical modulator of angiogenesis. Biochim Biophys Acta Mol basis Dis. 2017;1863(6):1326-35.

56. Tidball JG. Regulation of muscle growth and regeneration by the immune system. Nat Rev Immunol. 2017;17(3):165-78.

\section{Publisher's Note}

Springer Nature remains neutral with regard to jurisdictional claims in published maps and institutional affiliations.

\section{Ready to submit your research? Choose BMC and benefit from:}

- fast, convenient online submission

- thorough peer review by experienced researchers in your field

- rapid publication on acceptance

- support for research data, including large and complex data types

- gold Open Access which fosters wider collaboration and increased citations

- maximum visibility for your research: over $100 \mathrm{M}$ website views per year

At BMC, research is always in progress.

Learn more biomedcentral.com/submissions 